\title{
STANDAR KESELAMATAN PASIEN YANG WAJIB DI LAKSANAKAN DI RUMAH SAKIT
}

Trinitas bawaulu/181101043

Email: trinitasbawaulu04@gmail.com

\begin{abstract}
ABSTRAK
Standar pelayanan di Rumah Sakit, telah diterapkan pada sistem manajemen ISO, dan lainlainnya, yang mana dapat meningkatkan kualitas pelayanan di Rumah Sakit ditinjau dari aspek struktur, pada proses dan juga pada hasilnya. Kenyataannya masih terdapat peristiwa yang tidak diinginkan sehingga masyarakat merasa tidak puas dan terjadi tuntutan hukum. Dalam mengantisipasi hal tersebut dibutuhkan program keselamatan pasien (patient safety) dengan melibatkan pasien untuk memperbaiki pelayanan karena adanya terjadi peristiwa yang tidak diinginkan.

Tujuan: Untuk tenaga kesehatan dalam memberikan pelayanan kepada pasien dengan berkualiatas dengan tetap berpedoman pada standar keselamatan pasien di Rumah Sakit. Metode : Literature review ini melakukan analisa dan kajian bebas terhadap artikel, jurnal,text book, maupun ebook. Hasil : Setiap Rumah Sakit juga melaksanakan standar keselamatan pasien yang telah ditetapkan oleh permenkes. Pembahasan : Permenkes Nomor 16921/Menkes/Per/Viii/2011 tentang : standar yang wajib dimiliki oleh Rumah Sakit dalam menjalankan program keselamatan pasien.

Penutup: Ada tujuh standar keselamatan pasien (patient safety) yaitu hak pasien, mendidik pasien dan keluarga, keselamatan pasien dalam kesinambungan pelayanan, penggunaan metode peningkatan kinerja untuk melakukan evaluasi dan program peningkatan keselamatan pasien, mendidik staf tentang keselamatan pasien, dan komunikasi merupakan kunci bagi staf untuk mencapai keselamatan.
\end{abstract}

Kata kunci : patient safety, rumah sakit, tenaga kesehatan, klien.

\section{LATAR BELAKANG}
Keselamatan pasien adalah
(TKPRS RUSP Sanglah Denpasar, suatu sistem dalam mencegah terjadinya kecelakaan yang akibatkan oleh kesalahan akibat melakukan suatu tindakan atau tidak melakukan tindakan yang mestinya dilakukan 2011).
Keselamatan pasien rumah sakit merupakan suatu sistem yang dijalankan untuk mencegah terjadinya cedera akibat perawatan kesehatan 
dan kesalahan pengobatan melalui sistem assement resiko, pelaporan dan analisis insiden, kemampuan belajar dan tindak lanjut dari insident dan implementasi solusi untuk meminimalkan timbulnya risiko serta identifikasi dan pengelolaan faktor resiko (Depkes Ri, 2006).

Keselamatan psien berkaitan dengan "kualitas perawatan:, namun keduannya tersebut tidak sama. Keselamatan adalah hal terpenting dari kualitas. Hingga saat ini, kegiatan mengelola kualitas tidak terfokus secukupnya pada masalah keselamatan pasien (National Patien Safety Foundation, 2000, dalam Vincent, 2010).

Rumah Sakit adalah suatu tempat yang sangat kompleks, banyak ratusan macam obat, ratusan test prosedur, banyak terdapat teknologi dan alat, banyak profesi dan yang tidak profesi memberikan pelayanan kepada pasien selama 24 jam secar terus-menerus, banyak perbedaan dan keberagaman di pelayanan Rumah Sakit, bila tidak dikelola dengan baik bisa menyebabkan insiden keselamatan pasien berupa kejadian yang tidak diharapkan (KTD/Adverse event) (Depkes 2008).

Standar pelayanan di Rumah Sakit, telah diterapkan pada sistem manajemen ISO, dan lain-lainnya, yang mana dapat meningkatkan kualitas pelayanan di Rumah Sakit ditinjau dari aspek struktur, pada proses dan juga pada hasilnya. Kenyataannya masih terdapat peristiwa yang tidak diinginkan sehingga masyarakat merasa tidak puas dan terjadi tuntutan hukum. Dalam mengantisipasi hal tersebut dibutuhkan program keselamatan pasien (patient safety) dengan melibatkan pasien untuk memperbaiki pelayanan karena adanya terjadi peristiwa yang tidak diinginkan.

\section{TUJUAN}

\begin{tabular}{cc}
\multicolumn{2}{c}{ Bertujuan agar setiap } \\
mahasiswa keperawatan dapat
\end{tabular} mengetahui serta menganalisis apa saja yang menjadi standar keselamtan pasien di Rumah Sakit. Bagi perawat diharapkan dapat memberikan asuhan keperawatan yang benar dan tepat kepada pasien sehingga serta menjamin 
keselamatan pasien di Rumah Sakit. Untuk tenaga kesehatan dapat menjalankan setiap tugasnya di Rumah Sakit dalam memberikan pelayanan kepada pasien dengan berkualiatas dengan tetap berpedoman pada standar keselamatan pasien di Rumah Sakit.

\section{METODE}

Literature review ini melakukan analisa dan kajian bebas terhadap artikel, jurnal,text book, maupun ebook yang sesuai dan berfokus pada standar keselamatan pasien yang wajib dilaksanakan di Rumah Sakit. Kajian ini menggunakan 14 lebih artikel yang diterbitkan 10 tahun terakhir.

\section{HASIL}

Berdasarkan hasil pencarian literatur review ditemukan banyak standar-standar yang berlaku disetiap Rumah sakit.

Masing-masing Rumah sakit memiliki standar yang berbeda dari rumah sakit lainnya. Setiap Rumah Sakit juga melaksanakan standar keselamatan pasien yang telah ditetapkan oleh pihak-pihak yang berwenang dibidang kesehatan atau PERMENKES.
Terwujudnya

rencana-rencana penanggulan kecelakaan Joint Commision On Accreditation Of Healt Organizations, Illionois, USA, tahun 2002, mengeluarkan "Hospital Safety Standars" pada standarisasi di berbagai RS di Indonesia (Depkes, 2006).

Ada 7 standar keselamatan pasien dari Depkes yaitu:

Standar I

Merupakan hak pasien dalam mendapatkan berbagai macam keterangan tentang kecelakaan yang tak terduga.

a. Standar II

Mendidik pasien dan keluarga

b. Standar III

Keselamatan pasien dan kesinambungan pelayanan.

c. Standar IV

Evaluasi dalam rangka meningkatkan kinerja dalam meningkatkan keselamatan pasien.

d. Standar V

Peran kepemimpinan dalam meningkatkan keselamatan pasien

e. Standar VI.

Mendidik staf tentang keselamatan pasien 
f. Standar VII

Komunikasi adalah kunci bagi staf untuk mencapai keselamatan pasien Standar

\section{PEMBAHASAN}

PERMENKES

Nomor

16921/MENKES/PER/VIII/2011

tentang : standar yang wajib dimiliki oleh Rumah Sakit dalam menjalankan program keselamatan pasien.

\section{Standar I : Hak Pasien}

Pasien dan keluarga pasien mempunyai hak untuk mendapatkan informasi tentang rencana dan hasil pelayanan termasuk kemungkinan terjadinya kejadian yang tidak diharapkan (KTD).

Beberapa kriteria dari standar ini yaitu

1) Harus terdapat dokter penanggung jawab pelayanan.

2) Dokter penanggung jawab membuat rencana pelayanan kesehatan

3) Dokter yang menjadi penanggung jawab pelayanan wajib memberikan penjelasan secara jelas dan keluarganya tentang rencana dan hasil pelayanan pengobatan dan prosedur untuk pasien termasuk kemungkinan terjadinya KTD.

\section{Standar II. Mendidik pasien dan keluarga}

Rumah sakit harus mendidik pasien dan keluarganya tentang kewajiban dan tanggung jawab pasien dalam asuhan kesehatan pasien.

Beberapa kriteria dari standar tersebut antara lain :

Keselamatan pasiem dalam pemberian pelayanan dapat ditingkatkan dengan keterlibatan pasien yang merupakan partner dalam proses pelayanan. Karena itu Rumah Sakit harus ada sistem dan mekanisme mendidik pasien dan keluarganya tentang kewajiban dan tanggung jawab pasien dalam asuhan pasien.Dengan pendidikan tersebut diharapkan pasien dan keluarga dapat

1) Memberi informasi yang tepat, benar, jelas, lengkap, dan jujur.

2) Mengetahui kewajiban dan tanggung jawab pasien dan keluarga.

3) Mengajukan pertanyaan- 
pertanyaan untuk hal yang tidak dimengerti

4) Memahami dan menerima konsekuensi pelayanan kesehatan

5) Mematuhi instruksi dan menghormati peraturan rumah sakit

6) Memperlihatkan sikap menghormati dan tenggang rasa

7) Memenuhi kewajiban finansial yang disepakati

Standar III. Keselamatan pasien dan kesinambungan pelayanan.

Rumah sakit menjamin kesianambungan pelayanan kesehatan dan menjamin koordiansi anatr tenaga dan antar unit.

Beberapa kriteria dari standar itu yaitu

1) Memiliki koordinasi yang baik dari pelayanan kesehatan secara menyeluruh mulai dari saat pasien masuk, pemeriksaan, diagnosis, perencanaan pelayanan, tindakan pengobatan rujukan dan saat pasien keluar dari Rumah Sakit.
2) Mempunyai koordinasi pelayanan kesehatan yang disesuaikan dengan kebutuhan pasien dan kelayakan sumber daya secara berkesinambungan sehingga pada seluruh tahap pelayanan transaksi antar unit pelayanan kesehatan primer dapat berjalan baik dan lancar.

3) Memiliki koordinasi pelayanan yang mencakup peningkatan komunikasi untuk menfasilitasi dukungan keluarga, pelayanan keperawatan, pelayanan sosial, komsultasi dan rujukan, pelayanan kesehatan primer dan tindak lanjut lainnya.

4) Memiliki komunikasi dan transfer informasi antar profesi kesehatan sehingga dapat tercapainya proses koordinasi tanpa hambatan, aman dan tentram.

Standar IV. Penggunaan metodametoda peningkatan kinerja untuk melakukan evaluasi dan program peningkatan keselamatan pasien

Rumah Sakit harus mendesain proses baru atau memperbaiki proses 
yang ada, memonitor dan mengevaluasi kinerja melalui pengumpulam data-data, menganalisis secara intensif kejadian yang tidak diharapkan (KTD), serta melakukan perubahan untuk meningkatkan kinerja serta keselamatan pasien.

Beberapa kriteria dari standar ini yaitu

1) Setiap Rumah Sakit harus melaksanakan proses perencanaan yang baik dengan mengacu pada visi, misi, dan tujuan Rumah Sakit, kebutuhan pasien-petugas pelayanan kesehatan, kaidah klinis terkini, praktik bisnis yang sehat dan faktor-faktor lain yang berpotensi resiko bagi pasien sesuai dengan " tujuh langkah menuju keselamatan pasien di Rumah sakit".

2) Setiap rumah sakit harus melakukan pengumpulan datadata kinerja antara lain yang terkait dengan pelaporan insiden, akreditasi, manajemen resiko, utilisasi, mutu pelayanan dan keuangan.
3) Setiap Rumah Sakit harus melaksanakan evaluasi intensif terkait dengan semua KTD/KNC, dan secara proaktif melakukan evaluasi suatu proses kasus resiko tinggi bagi pasien.

4) Setiap Rumah Sakit harus mempergunakan semua data dan informasi hasil analisis untuk menentukan perubahan sistem yang diperlukan agar kinerja dan keselamatan pasien terjamin.

\section{Standar V. Peran kepemimpinan dalam meningkatkan keselamatan pasien}

a. Pimpinan mendorong dan menjamin pelaksanaan program keselamatan pasien secara terintegrasi dalam organisasi melalui penerapan " tujuh langkah menuju keselamtan pasien di Rumah Sakit".

b. Pimpinan menjamin keberlangsunggan program proaktif dalam mengidentifikasi risiko keselamtan pasien dan 
program untuk menekan atau mengurangi kejadian yang tidak diharapkan.

c. Pimpinan mendorong dan menumbuhkan komunikasi dan koordiansi antar unit setiap individu terkait dengan pengambilan keputusan tentang keselamatan pasien.

d. Pimpinan mengalokasikan sumber daya yang adekuat untuk mengkaji, mengukur, dan meningkatkan kinerja Rumah Sakit serta meningkatkan keselamatan pasien.

e. Pimpinan mengkaji dan mengukur efektifitas kontribusinya dalam meningkatkan kinerja Rumah sakit dan keselamatan pasien.

Beberpa kriteria dari standar ini yaitu:

1) Terdapat tim antar disiplin untuk mengelola program keselamatan pasien guna meningkatkan mutu pelayanan Rumah Sakit.

2) Tersedia program proaktif untuk mengidentifikasi risiko keselamtan dan program meminimalkan insiden yang mencakup jenis kejadian yang memerlukan perhatian, mulai dari kejadian nyaris cedera (near miss) sampai kejadian tidak diharapkan (adverse event)

3) Tersedianya mekanisme kerja untuk menjamin bahwa semua komponen dari rumah sakit terintegrasi serta berpartisipasi dalam program keselamatan pasien.

4) Tersedia prosedur yang cepat tanggap terhadap insiden, termasuk asuhan kepada pasien yang terkena musibah, membatasi resiko kepada orang lain dan penyampaian informasi yang benar dan jelas untuk keperluan analisis.

5) Tersedia mekanisme pelaporan baik internal dan eksternal yang berkaitan dengan insiden termasuk penyediaan informasi yang benar dan jelas tentang analisis akar masalah (RCA) kejadian saat program keselamatan pasien mulai dilaksanakan. 
6) Tersedia mekanisme untuk menangani berbagai jenis insiden atau kegiatan proaktif untuk memperkecil resiko termasuk mekanisme untuk mendukung staf dalam kaitan dengan kejadian yang tidak diinginkan.

7) Terdapat kolaborasi dengan komunikasi terbuka secara sukarela antar unit dan antar pengelola pelayanan di dalam Rumah Sakit dengan pendekatan antar disiplin.

8) Tersedia sumber daya dan sistem informasi yang dibutuhkan dalam kegiatan perbaikan kinerja Rumah Sakit dan perbaikan Keselamatan Pasien, termasuk evaluasi berkala terhadap kecukupan sumber daya tersebut.

9) Tersedia sasaran terukur dan pengumpulan informasi menggunakan kriteria obyektif untuk mengevaluasi efektifitas perbaikan kinerja Rumah Sakit dan keselamatan pasien, termasuk rencana tindak lanjut dan pelaksanaannya.
Standar VI. Mendidik staf tentang keselamatan pasien

a. Rumah Sakit mempunyai pendidikan, pelatihan dan orientasi untuk setiap jabatan mencakup keterkaitan jabatan dengan keselamatan pasien secara transparan dan jelas.

b. Rumah Sakit mengadakan program pendidikan dan pelatihan yang berkelanjutan untuk meningkatkan dan memelihara kompetensi staf serta mendukung pendekatan interdisplin dalam pelayanan pasien.

Beberapa kriteria dari standar ini yaitu

1) Setiap Rumah Sakit mempunyai program pendidikan, pelatihan dan orientasi bagi staf baru yang memuat topik tentang keselamatan pasien sesuai dengan tugasnya masingmasing.

2) Setiap Rumah Sakit harus mengutamakan keselamtan pasien dalam setiap tindakn 
inservice training dan memberi pedoman yang jelas tentang pelaporan insiden.

3) Setiap Rumah Sakit melaksanakan training tentang kerjasama kelompok guna mendukung pendekatan interdisiplin dan kolaboratif dalam rangka melayani pasien.

Standar VII. Komunikasi adalah kunci bagi staf untuk mencapai keselamatan pasien

a. Rumah Sakit harus merencanakan dan mendesain proses manajemen informasi keselamtan pasien untuk memenuhi kebutuhan informasi internal dan eksternal.

b. Transmisi data dan informasi harus tepat waktu dan akurat.

Beberapa kriteria dari standar ini yaitu:

1) Rumah Sakit harus menyediakan anggaran untuk mendesain dan merencanakan proses manajemen dalam memperoleh data dan informasi tentang hal-hal terkait dengan keselamatan pasien.
2) Tersedia mekanisme untuk mengidentifikasi masalah dan kendala komunikasi untuk merevisi manajemen informasi yang ada.

\section{PENUTUP}

\section{A. kesimpulan}

Semua rumah sakit wajib untuk menerapkan standar keselamatan pasien (patient safety) menurut PERMENKES

16921/MENKES/PER/VIII/2011. Ada tujuh standar keselamatan pasien (patient safety) tersebut adalah hak pasien, mendidik pasien dan keluarga, keselamatan pasien dalam kesinambungan pelayanan, penggunaan metode peningkatan kinerja untuk melakukan evaluasi dan program peningkatan keselamatan pasien, mendidik staf tentang keselamatan pasien, dan komunikasi merupakan kunci bagi staf untuk mencapai keselamatan.

\section{B. Saran}

Penerapan tujuh standar keselamatan pasien di Rumah Sakit wajib di lakukan oleh 
tenaga kesehatan yang bertugas di dalam Rumah Sakit supaya tindakan yang dilakukan tidak menimbulkan kerugian maupun membahayakan bagi pasien.

\section{REFERENSI}

Aditama, T. Y. (2006). Kesehatan dan Keselamatan Kerja. Jakarta: Penerbit Universitas Indonesia (UI-Press).

Astuti, T. P. (2013). Analisis Penerapan Manajemen Pasien Safety Dalam Rangka Peningkatan Mutu Pelayanan di Rumah Sakit PKU Muhammadiyah. Surakarta.

Cahyono, agung. (2015). Hubungan Karakteristik dan Tingkat Pengetahuan Perawat Terhadap Penggelolan Keselamatan Pasien di Rumah Sakit. Jurnal ilmiah widya. Vol 3(2) : 97-102.

Deswani. (2009). Proses Keperawatan dan Berpikir Kritis. Jakarta: Salemba Medika.

Departemen Kesehatan RI. (2011).
Panduan

Nasional

Keselamatan Pasien Rumah

Sakit (Patient Safety). Jakarta:

Depkes RI.

Departemen kesehatan R.I. (2006).

Panduan nasional

keselamatan pasien rumah

sakit. Utamakan keselamatan

pasien. Bakti Husada

Hakim, L., \& Pudjirahardjo, W. J. (2014). Optimalisasi Proses KoordinasiProgram Keselamatan Pasien(Patient Safety) di Rumah Sakit X Surabaya. Jurnal Administrasi Kesehatan Indonesia Volume 2 Nomor 3.

Herawati, T. (2011). Keselamatan Pasien Dalam Keperawatan : dalam Workshop Keselamatan Pasien dan Manajemen Resiko Klinis Di Rumah Sakit. Perhimpunan Rumah Sakit seluruh Indonesia

Kemenkes RI. (2013). Panduan keselamatan pasien. Jakarta Kuntoro, A. (2010). Buku Ajar Manajemen Keperawatan. Yogyakarta: Nuha Medika 
Nurjaman, Kadar \& Khaerul Uman. (2012). Komunikasi \& Publik Relation. Bandung : Pustaka Setia

Nursalam. (2008). Konsep Dan Penerapan Metodologi Penelitian IImu Keperawatan. Jakarta : salemba Medika

Potter \& Perry. (2005). Fundamental keperawatan: konsep proses \& praktek. Jakarta: salemba medika

Simamora, R. H. (2018). Buku Ajar Keselamatan Pasien Melalui Timbsng Terima Pasien Berbasis Komunikasi Efektif : SBAR. 2018.

Tutiany., Lindawati. (2017).

Manajemen Keselamatan Pasien. Kementerian R.I 